\title{
Assessing divergent development trajectories: Schumpeterian competition, finance and financial governance*
}

\author{
Leonardo Burlamaqui** \\ Rainer Kattel ${ }^{* *}$
}

Recebido: 29/01/2015 Versão Revisada (entregue): 24/08/2015 Aprovado: 28/08/2015

\begin{abstract}
The paper offers four propositions for discussion. First, it argues that instead of the oftenassumed convergence among nations, history shows us that divergence is a more appropriate way to conceptualize development trajectories; and that this is especially visible in the last century. Secondly, the paper suggests that "convergence" and "catch-up" are, from a Schumpeterian perspective, theoretically inadequate concepts as they frame development narratives similarly to the Rostovian idea of a linear path towards some sort of "development equilibrium". Thirdly, we outline this schumpeterian framework, centered on the concept of leapfrogging through innovation and finance. The paper concludes by pointing out that macrofinancial coherence and "robust" economic governance (the role of the State playing a key role here) are essential dimensions - although scarcely researched of such alternative framework - for understanding development trajectories.
\end{abstract}

KEYWORDS | Development; Finance; Competition; Leapfrogging; Schumpeter

JEL-CODES: O1; O33; O38

* This is a substantial further development of our previous paper, Burlamaqui and Kattel (2014). The authors would like to thank Jan Kregel for comments to an earlier draft of the paper and to the two anonymous reviewers whose sharp questions and suggestions helped us to refine a number of points. The usual disclaimers apply.

** Universidade do Estado do Rio de Janeiro, Rio de Janeiro (RJ), Brasil. E-mail: leonardo.burlamaqui@gmail.com

*** Tallinn University of Technology, Estonia. E-mail: rainer.kattel@ttu.ee 


\section{Compreendendo trajetórias divergentes de desenvolvimento: concorrência Schumpeteriana, finanças e governança financeira}

\section{Resumo}

No presente trabalho discute-se que divergência - e não convergência - tecnológica ou de trajetórias de desenvolvimento é a norma na história do desenvolvimento, sendo um fenômeno especialmente visível no último século, e que convergência e catch-up são, de uma perspectiva calcada na concorrência Schumpeteriana, conceitos teoricamente inadequados para explicar as referidas trajetórias, pois ambos implicam uma espécie de "equilíbrio imposto à história". São propostos, aqui, de forma compacta, os contornos de uma abordagem analítica centrada no conceito de leapfrogging (ultrapassagem) pela via das inovações aliada à participação ativa do sistema de crédito. $\mathrm{O}$ estudo salienta a importância da macrofinança - em particular a estrutura do sistema financeiro e sua relação com os processos de financiamento e com a governança econômica (destacando aí o papel do Estado) - como elemento tão importante, ainda que pouco pesquisado, quanto as variáveis tecnológicas nas teorias do desenvolvimento, quando se trata de explicar trajetórias bem-sucedidas.

PALAVRAS-CHAVE | Desenvolvimento; Finanças; Concorrência; Ultrapassagem; Schumpeter Códigos JEL | O1; O33; O38 


\section{Introduction}

This paper aims to show that development processes and trajectories are better understood within a Schumpeterian approach. A key point we make is that these processes typically lead to divergence, not convergence or even "catch-up". We suggest Schumpeterian competition is the linchpin of differentiation, not homogenization, and that differentiation is an essential dimension of economic evolution. In a Hirschmanian parlance this translates into development as an un-balanced growth process (HIRSCHMAN, 1958; ADELMAN, 2013). In fact, the policy message we offer is that promoting economic development requires very distinctive policy tools - and changing them as the process evolves - as well as continuous institutional reforms. The theoretical backing for this policy perspective is that successful (and rapid) development processes involve leapfrogging rather than a path towards convergence or catching up. In other words, development, both successful or not, is not a continuous and orderly but rather an abrupt and conflict-prone process. In that context, catching-up is not an "end state", but a prelude to either soaring ahead or falling behind.

The paper offers four propositions for discussion in this context. First, it argues that instead of the often-assumed convergence among nations, history shows us that divergence is a more appropriate way to conceptualize development trajectories; and that this is especially visible in the last half a century. Second, it suggests that "convergence" and "catch-up" are, from a Schumpeterian perspective, theoretically inadequate concepts as they frame development narratives similarly to the Rostovian idea of a linear path towards some sort of "development equilibrium" (the technological frontier). We call this "equilibrium imposed on history". Third, it outlines this Schumpeterian framework, centered on the concept of leapfrogging through innovation and finance, ${ }^{1}$ as a more promising way to address both development theory and the historical trajectories observed since the industrial revolution in Britain. Finally, the paper points out that besides credit, macrofinancial coherence and "robust" State-led financial governance are essential but underdeveloped - dimensions of Schumpeter's framework and should become objects of inquire for improving it. At that point, we seek help in Keynes's ideas and

1 Recall that in Schumpeter's framework development begins with entrepreneurship, credit and innovation. The "credit" part was largely forgotten in the neo-shumpeterian literature. Perez (2002) is an attempt to reincorporate finance into the evolutionary process, Kregel and Burlamaqui (2005) is another one. See also O'Sullivan (2006) for further insights in the same direction. Our claim is that those are efforts to reclaim and extend the original Schumpeterian perspective rather than to refine the neoshumpeterian approach. 
in the financial Keynesianism literature initiated by Keynes himself and developed by several authors, in particular Hyman Minsky and Jan Kregel.

In that regard, we submit that while finance was already a core element in Schumpeter's analysis, a more refined elaboration of its role came with Keynes, Minsky and Kregel. Keynes introduced money and financial market's expectations as central features of the system's dynamics (KEYNES, 1936; KREGEL, 1998). Minsky extended that view through the "Wall Street Paradigm" where capitalism is conceived as essentially a financial system, and prone to waves of financial fragility and economic vulnerability (MINSKY, 1982, 1986). Kregel broadened Minsky's theories by linking them to development as well as introducing exchange rate instability, derivatives and the "international dimension" to our understanding of how the financial structure of an economy is, always, a key element of its development path (KREGEL, 1998, 2001a, 2001b, 2010; KREGEL; BURLAMAQUI, 2005).

The novelty here is not "financing for development", but macrofinance: the way the financial system works and how it should be structured and governed to effectively foster innovation and development. We use this body of work to attempt a bridging process and propose that successful development processes are necessarily coupled with pro-active "industrial finance" oriented financial structures and robust economic and financial governance. We suggest that this particular policy and institutional package enables countries to continuously upgrade their technological and innovation capabilities and engage in a strategy of following as a prelude for surpassing.

A core point we are making here is to suggest, following Minsky, that capitalism is essentially a financial system (which may deteriorate into a collection of 'Ponzi Nations', as it did in 2008). However, we are also adding a Schumpeterian dimension, by pointing out that under certain institutional and financial arrangements, not yet fully explored from a theoretical perspective, it may also become an innovation system creating wealth and a positive sum game for the economy.

This framework might help us to rethink how both domestic and international policymaking bodies should think about development processes and in particular how domestic growth and competitiveness policies could be re-shaped.

Before we proceed, let us be clear about what we want to propose. In one sense, what we are arguing runs close to what Amsden and Hikino (1994) have submitted as a "new learning paradigm" to assess late industrialization. In their contribution to the well-known Baumol, Nelson and Wolff (1994) volume on convergence and catch-up they explicitly advance the leapfrogging hypothesis: "Leading American and German 
enterprises could and did leapfrog ahead of Britain in the most dynamic sectors such as chemicals and steel because British firms could not establish impenetrable international entry barriers in the nineteenth century" (AMSDEN; HIKINO, 1994, p. 289). However, this competition dynamics is not taken as an ongoing evolutionary process, but quickly dismissed as an historical episode: "By the twentieth century this strategy had become impractical” (AMSDEN; HIKINO, 1994, p. 289).

We disagree with that interpretation. In ours, as we will try to show, leapfrogging is an intrinsic feature of success in Schumpeterian competition. It happened with American and German enterprises in the nineteen century, but also with Toyota, Fanuc, Nokia and Acer in the twentieth and is happening with Google, Apple, Samsung and Huawei in the twenty-first.

Considering this, our claim is either broader or narrower, depending on the perspective one adopts. It is broader in the sense that we are indicating that there is nothing intrinsically new about late industrialization. An appropriate analytical framework for analyzing development processes - "late or early" - is what is missing. ${ }^{2}$ It is narrower in the sense we are not claiming to have invented this analytical framework, we are just borrowing from Schumpeter, Keynes, Minsky and Kregel and, maybe, doing - at most - some creative adaptation. ${ }^{3}$

\section{Converging policies, diverging trajectories}

Since the Washington Consensus (WC) policy package's take over in the $1980 \mathrm{~s}^{4}$ and the creation of WTO in 1995, we witness a growing homogeneity among development policies. While emulation of successful policies is historically nothing new (REINERT, E., 2009a; REINERT, S., 2011), both the WC and the WTO and its descendants (e.g., bilateral agreements) assume universal rules and institutions that should be replicated by the developing countries. All these agreements internationally

2 An important clarification at this point is that we are certainly aware of the crucial role of industrial and technology policies to "continuously upgrade" Schumpeterian competition. The State was/is a key player in all successful cases of leapfrogging and we plan to elaborate further on that mater in a follow-up paper. In this piece the choice was to try linking development with Schumpeterian competition and seeking bridges between the former and the so-called financial Keynesianism. For excellent recent discussions of the role of the State in shaping industrial and technology policies in the US, see Block and Keller (2011) and Weiss (2014). For a brief discussion of the Chinese Entrepreneurial State, see Burlamaqui (2015).

3 Furthermore, Schumpeter had important predecessors (such as Marx, Sombart and Veblen, among others) and successors (such as Freeman, Rosenberg, Nelson, and Winter among others). In what follows we use Schumpeter as our departing point because in our understanding he provides the best combination between a bird's eye view of capitalist dynamics - combining economics, sociology, politics and culture - with a permanent quest for theoretical and analytical deepness.

4 Which was also embraced by most of Asian countries until the Asian crisis but with less and less emphasis after that. 
regulate areas that were previously typically left to countries themselves to govern. ${ }^{5}$ Consequently, what we witness during past 30 years is a strong convergence in formal policies - from patent policies to financial regulation (see also KARO; KATTEL, 2010). Notwithstanding, this increasing policy convergence leads, not surprisingly if looked from the perspective we are suggesting, to diverging economic fortunes. The reason for that is quite clear: economic agents are creative and firms are agents of transformation. Therefore, in spite of converging policies and rules, seeking for change in order to gain market niches is what keeps moving them; and divergence the outcome. In what follows, we do not intend to give an exhaustive empirical overview of divergence; rather we offer only snapshots of development trajectories, but hope this extremely condensed discussion suffices to query the idea that successful development trajectories should be understood as processes of convergence and catching up at work in the global economy.

As Figure 1 shows, if we take US GDP per capita as the goal all development processes should converge and catch up towards, we see that during the last 60 years there is no clear trend of catching up or convergence globally. Indeed, judging from this figure, one can even argue that with the onset of WTO, divergence between regions and between countries has in fact become much more pronounced.

FIGURE 1

GDP per capita as a \% of US GDP per capita, regional simple averages, in 1990 (in US\$)

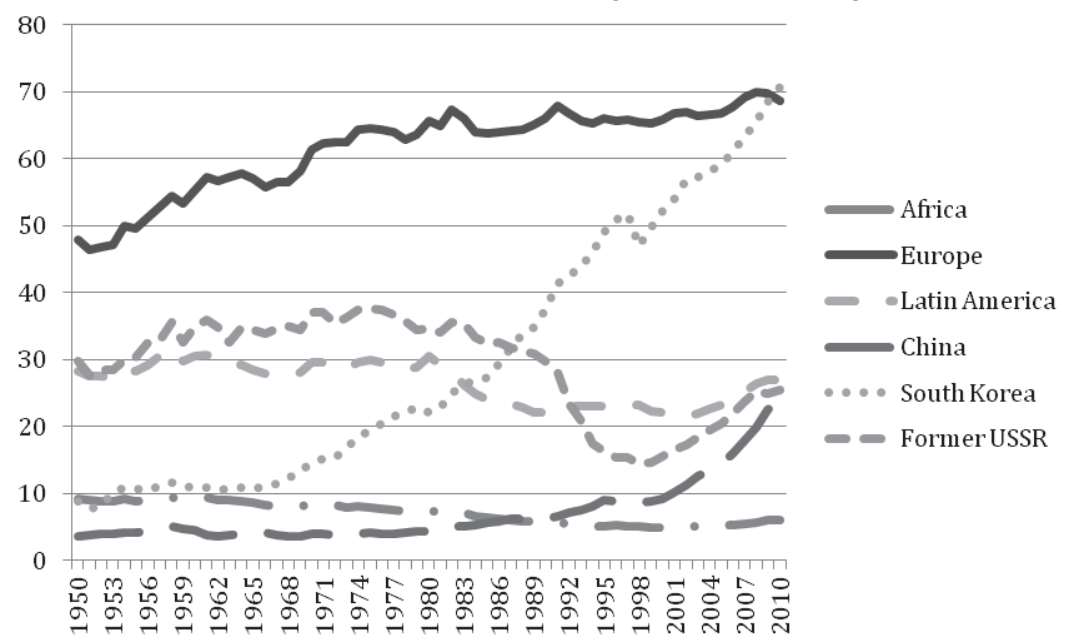

Source: The Conference Board and Groningen Growth and Development Centre, Total Economy Database, extracted March 2012. Available at: <http://www.conference-board.org/economics/>; calculations by the authors.

5 Many heterodox economists have discussed the impact of WTO on development; thus, e.g., Wade (2003), Gallagher (2005), Shadlen (2003, 2005), Correa (2000), Li and Correa (2009), and Thrasher and Gallagher (2008) offer useful summaries of these discussions. 
Indeed, we see impressive success stories such as Japan, South Korea, Taiwan and Singapore, that have not only caught up with Western Europe and US but, in the process, changed both the technological and business organization frontiers, leapfrogged "Western" best practices and completely left behind Latin America and what used to be called Soviet Union. In particular the latter region, Eastern Europe and former Soviet republics, experienced massive changes in 1990s and fell rapidly behind East Asian economies that were substantially less developed and poorer only a few decades earlier. As Guerrieri argued already in 1998 - less than a decade after the fall of the Berlin Wall -, the East Asian economies "have surpassed Eastern Europe in many industries, not only in traditional product groups, but also in more technologically sophisticated sectors" and this is particularly so in "RD-intensive (science based) sectors" (GUERRIERI, 1998, p. 20). While Eastern European share in world trade grew from $0.73 \%$ in 1980 to $0.95 \%$ in 1995 , East Asia's share grew in the same period from $3.80 \%$ to $10.83 \%$ (GUERRIERI, 1998, p. 29). This trend is particularly pronounced for science-based industries: Eastern Europe's share grew from $0.29 \%$ to $0.39 \%$ in the period from 1980 to 1995; East Asia's share grew from 4.83\% to staggering 17.82\% (GUERRIERI, 1998, p. 38). One can argue that the transition of Soviet Union was a particularly badly managed process where looting and theft were the norm. Furthermore, if we look at Eastern European countries, such as Hungary, early transition success story with high levels of FDI and high technology exports, we still see a surprisingly similar picture. Figure 2 depicts South Korea's and Hungary's highly diverging fortunes during 25 years since 1980. While South Korea's GDP per capita more than quadrupled during this period, Hungary rapidly deindustrializes and her GDP per capita barely raises above the 1980 level by 2005 . 
FIGURE 2

GDP per person employed, index $(1980=100)$ (left axis), and industry value added as \% of GDP (right axis)

Korea and Hungary - 1980-2005

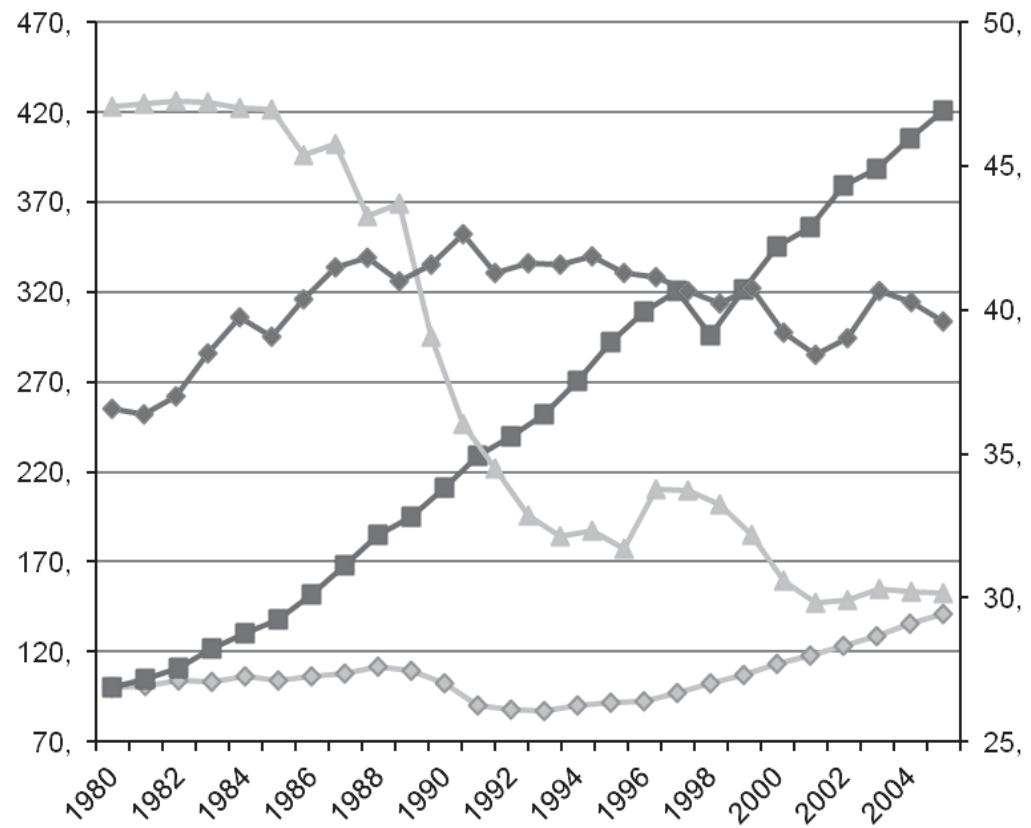

- Hungary GDP per person employed, index $(1980=100)$
$=$ Korea GDP per person employed, index $(1980=100)$
$=$ Hungary industry value added \% of GDP
$=$ Korea industryvalue added \% of GDP

Source: World Bank WDI Online database.

Today, China is doing - on steroids - precisely the same as South Korea and other Asian tigers did during the previous decades. If we take, for instance, the development paths followed by Russia and China since the late 1980s, it is clear that there is no convergence whatsoever, but accumulating divergence. As Nee states: "While in 1990 China's gross domestic product (GDP) was 60 percent that of Russia, by the end of the decade the numbers had been reversed. While Russia saw an unprecedented increase in poverty, China saw an unprecedented decrease" (NEE, 2007, p. 6). According to the World Bank (2004), transformative economic growth in China resulted in a population of 170 million moving out of absolute poverty, accounting for more than 75 percent of poverty reduction in the developing world from 1990 to 2000 . China's explosive economic growth has 
shown to have self-sustaining momentum. By 2040, The Economist (16 September $2006,10)$ predicts China will emerge as the largest economy in the world. Not surprisingly, international economic institutions now view China as the latest entry in the pantheon of successful developmental trajectories, along with South Korea, Taiwan and Japan.

A comparison of Asia and Latin America leads us to similar results: no convergence or catching up, but another case of continuous divergence. In a recently published book on the subject, Kevin Gallagher and Roberto Porzecanski, using China as a proxy for East Asia, succinctly illustrates the point:

China and the Latin American-Caribbean region (LAC) began to implement economic reforms within a few years of each other; China in 1978, much of Latin America in 1982. In 1980, the collective economic output of Latin America and the Caribbean was seven times that of China - 14 times greater on a per-capita basis. Nearly 30 years later, China had pulled ahead, with gross domestic product of $\$ 2.7$ trillion in 2009 versus pan-regional GDP of $\$ 2.6$ trillion in Latin America. Over the three decades, China registered a robust annual economic growth rate of eight percent. The average annual rate in Latin America has been a more modest 3.8 percent. Between 1980 and 2009, GDP per capita increased by 6.6 percent annually in China, while in Latin America, per-capita GDP edged up by a mere 1.7 percent annually during years that were marked by crises and volatility. (GALLAGHER; PORZECANSKI, 2011, chapter 1, p. 14)

Divergence between China and Latin America as measured in their respective shares in world's manufacturing exports is illustrated by Figure 3 below: China's share keeps climbing, while most of Latin American countries see their shares diminish.

Furthermore, if we look within Asia and Latin America individually, divergence shows up once more. In Asia, China is the country clearly forging ahead from all others; in Latin America, Brazil performs partially the same role. Also within Eastern Europe we do not see convergence, thus for instance Poland did not experience any recession during the recent economic and financial crisis, while the Baltic economies saw their GDP drop in 2009 more than 15\% (KATTEL, 2010).

However, convergence does not describe development trajectories among highly developed nations either. If we look at dynamics of income growth among European nations since 1950s we see that some nations such as Ireland have enjoyed rapid growth and in fact have forged ahead of most developed countries in Europe while others such as Italy and other Southern European economies are falling behind, in particular since the single market came to force in Europe in mid-1980s. 
FIGURE 3

Country shares in world manufacturing exports listed as positions among top 50 exporting countries

Selected countries - 1980-2005

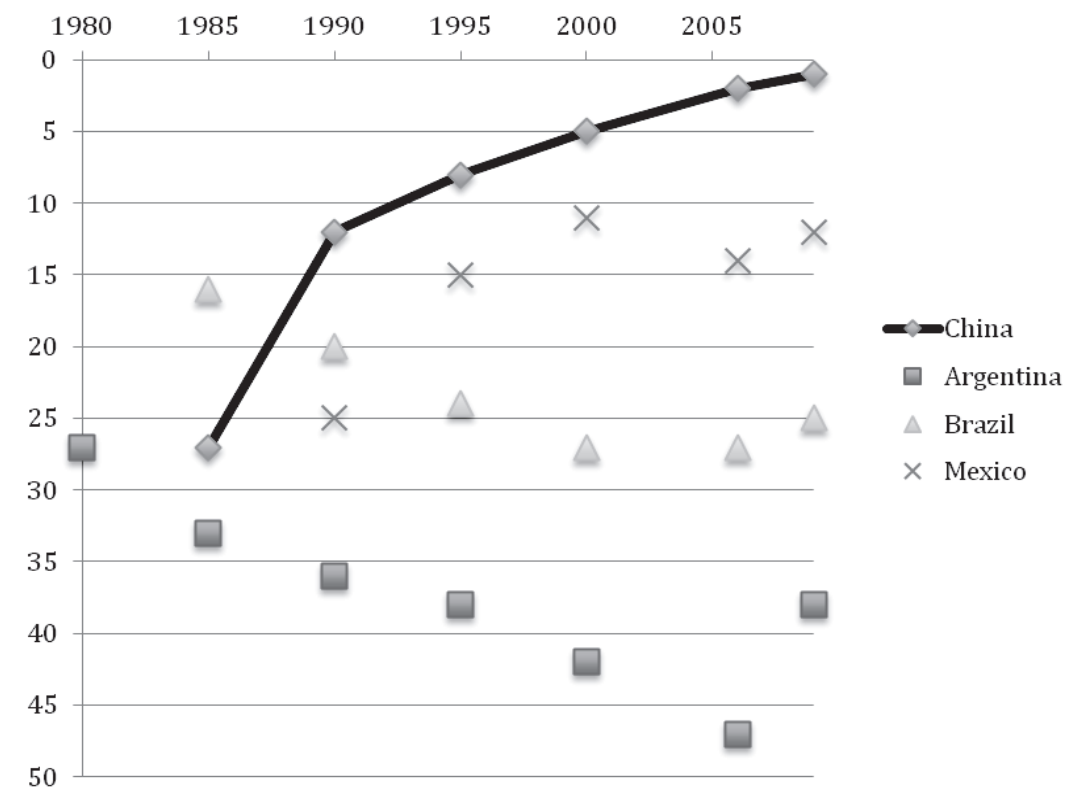

Source: Data drawn from Gallagher and Porzecanski (2011).

FIGURE 4

GDP per capita as a \% of German GDP per capita, regional simple averages, in 1990 GK\$ Selected countries - 1950-2010

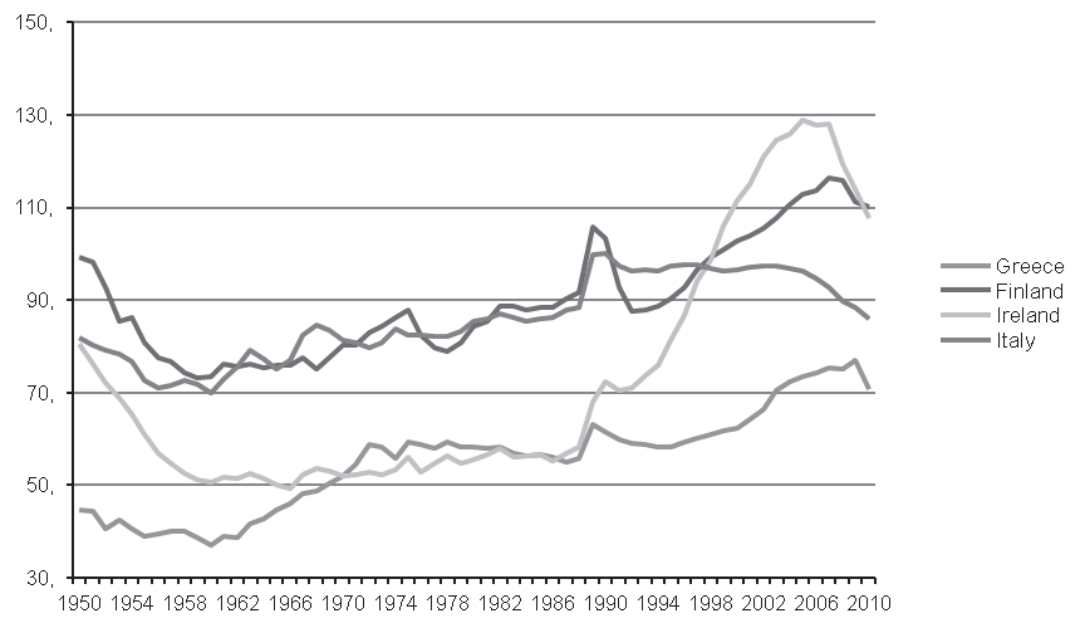

Source: The Conference Board and Groningen Growth and Development Centre, Total Economy Database, extracted March 2012. Available at: <http://www.conference-board.org/economics/>; calculations by the authors. 
Consequently, it is safe to assume that there are different dynamics going on among nations rather than convergence or catching up. Here, a more skeptical and historically minded reader might ask: even if that is true for the last three or four decades, what if we go back to the "classical" period of convergence and catchup stories, the "Gerschenkronian" 19th and early 20th centuries? The answer to that question is the same: in fact what happened in the comparative histories of industrialization in Britain, USA, Continental Europe (especially Germany) and Japan was "industrial finance" and creative destruction leading to leapfrogging, not catching up and convergence. What history shows is a succession of episodes of corporations, industries and countries - but especially corporations and industries - overtaking others and becoming leaders. Thus, for instance, by introducing new methods of production, organization, financing as well as new institutional arrangements, Germany managed - around the turn to the 20th century - to surpass Britain in steel, chemistry, electricity, big pharma, investment banking and corporate-based research (LANDES, 1969, WATSON, 2011).

Similarly, what Japan did, in fact, was to introduce, along with industry specific innovations, a new set of institutional innovations to foster development by means of a very coherent industrial policy (building on Germany, and the US, as we know). As a result, Japan did not "converge" with the West. It leapfrogged Europe and became "number two", threatening to displace the US as number one by the 1980s. Its 1990's financial bubble buried this goal - at least for now - but the "Governing the Market" development strategy perfected by Japan, adopted later by its neighbors and now being re-invented by China, enabled it to at least for some time leapfrog and surpass technologically, rather than converge with, most of the developed world (VOGEL, 1979; JOHNSON, 1982; DORE, 1987; FRUIN, 1992; STUDWELL, 2013).

Conceptually speaking, this is precisely what Britain, Germany, and the US had done before. Leapfrogging through powerful paradigm and/or frontier changing innovations, not convergence or catching up (PEREZ, 2002). The theoretical framework best suited to understand these processes is, we argue, Schumpeterian: Schumpeterian competition and creative destruction performed with borrowed money, embedded into the wider institutional framework and leading to differentiation, stumbling back, sneaking up and soaring ahead. Before we show the broad contours of that framework, we must take a brief detour and critically appraise the concepts of convergence and catch-up processes. 


\section{Convergence and catch-up: equilibrium in development trajectories?}

There are many theories that try to explain convergence and catching up. In essence, almost all economic development theories that deal with long-term economic growth, one way or the other, touch upon convergence. What follows is again but a snapshot of theories dealing with convergence and catch-up, and is not meant to be an exhaustive treatment. Largely, these theories can be divided into two large schools of thought: first, theories that explicitly or implicitly assume that nations will eventually converge towards an equilibrium; second, theories that understand international economic development through stages. ${ }^{6}$

Convergence theories tend to assume that technology and innovation are exogenous to development and more or less freely available to all, and that countries are similar to each other but for the productive structures. Essentially, for these theories, development is a matter of copying best practice solutions and about getting the institutions right for such copying (BOYER, 1993). Convergence theories assume, in sum, that there is one best route to development (in terms of technological, organizational and financial capabilities exhibited by leading firms) in any given point in time and that countries which follow it will converge towards similar levels of productivity and per-capita income. Policy and institutions, including international trade agreements, would foster the movement of all countries towards such "equilibrium imposed on history", or are hindrance to expected convergence.

Considering catch-up, it seems to be one of those "general purpose concepts", given the multiple uses it allows. In a recent book, Odagiri et. al. (2011, p. 2-3) provide the following definition: "Catch-up may be defined as the process in which a late-developing country narrows its gap in income (as one may specify by the word 'economic catch-up') and in technological capability (equally 'technological catchup') vis-à-vis a leading country". In addition: "This fact has been evident since, say, the Industrial Revolution of the 18th Century and is now even more so as many industries became technology-intensive". One cannot say that this is a particularly precise definition. It is more like a reference to a multidimensional process that some countries go through and others do not. The authors acknowledge that point even before introducing the concept: "To be sure, some countries did catch-up and some even forged ahead. Some, however, actually fell behind" (ODAGIRI et al., 2011, p. 2).

6 See Rostow (1960), for the classic statement, and Baumol, Nelson and Wolff (1994), for further elaboration. 
This imprecision seems to create a conceptual problem: is catch-up a tendency or a possibility (some achieve it, some do not) for late developers? Furthermore, catching-up seems to imply "convergence" (narrowing the income gap) and, apparently, some kind of alignment at the technological frontier, in which case that frontier must be seen as a well defined object that moves incrementally, as in a Solow-Swan growth model. However, if some late developers actually "forge ahead", then neither convergence nor alignment are sure to happen.

Before we conclude this brief discussion, a mandatory mention to Alexander Gerschenkron is due. Gerschenkron, the doyen of economic history in the United States during the fifties and sixties, was a product of the same milieu Schumpeter has lived, and, like Schumpeter himself, influenced a whole generation of Harvard economists through his required graduate course in economic history (FISHLOW, 2001). Although often associated with catch-up narratives, his thesis on the "advantages of backwardness" (GERSCHENKRON, 1962, chapter 1) puts him far away from stages theories a la Rostow, and brings him very close to our proposed "leapfrogging hypothesis". In his 2001 review of the classic book, Fishlow provides a concise and well-balanced perspective pointing towards that conclusion:

Gerschenkron's analysis is conspicuously anti-Marxian. It rejected the English Industrial Revolution as the normal pattern of industrial development and deprived the original accumulation of capital of its central force in determining subsequent expansion. It is likewise anti-Rostovian. There were no equivalent stages of economic growth in all participants. Elements of modernity and backwardness could survive side by side, and did, in a systematic fashion. Apparently, disadvantageous initial conditions of access to capital could be overcome through new institutional arrangements. Success was indicated by proportionally more rapid growth in later developers, signaled by a decisive spurt in industrial expansion. (FISHLOW, 2001, p. 1)

We cannot delve into a comprehensive discussion of that controversial matter here but would like to suggest that his thesis, more historically than theoretically crafted, sides more with Schumpeterian leapfrogging processes than with the other development theories just discussed. An important follow up on this line of reasoning would get us to look deeper into Hirschman and the Cepal pioneers such as Prebisch and Furtado, which also developed their perspectives and policy recommendations 
along the same Gerschenkronian approach. ${ }^{7}$ However, space does not allow for that important theme here. It deserves a paper of its own.

Let us conclude this section by re-stating one of our initial points: "convergence" and "catch-up" are rather loose ways (or concepts) to frame development narratives and more akin to the idea of a tendency towards equilibrium imposed on history. After all, what it really says is that once a nation manages to "develop" by reaching the existing, given technological frontier (a process that may or may not happen), it tends to "stay there", or that development once achieved is self-sustaining, but maybe not even that, since nations can also "forge ahead or fall behind". In order to get a firmer grasp of these processes of structural change where catching-up is temporary, and just a prelude for forging ahead or falling behind, let's move to the Schumpeterian terrain, and to an alternative framework.

\section{Divergent development trajectories: Schumpeterian competition by means of innovation, leapfrogging and finance}

Economics as a scientific discipline starts with development-oriented questions, such as why some cities, like Venice, surged ahead while others, like Naples, fell behind. In that regard, Antonio Serra's 1613 highly significant treatise, titled as $A$ short treatise on the causes that make kingdoms abound in gold and silver even in the absence of mines, with particular reference to the Kingdom of Naples should be taken as a well-argued starting point. It is no coincidence that Schumpeter greatly praised Serra since he defined capitalism as a process grounded on wealth creation (of new things 'competing old things out of existence' - 1939, 228). To that matter, his perhaps oversimplified reflection of Sombart and Weber is telling: Schumpeter argues that it makes no sense to look for a new spirit or new rationalism in order to "decode" capitalism, it is rather the process by which capitalism incessantly moves forward - innovations and their impact on competition - that economists should try to understand ${ }^{8}$ (SCHUMPETER, 1939, p. 227).

Furthermore, Schumpeter's theory of innovation is an application to economics and business of his wider theory of how evolutionary change takes place in societies

7 See Adelman (2013) for a good overview.

8 Here it is worth mentioning that Schumpeter was probably not familiar with Weber's mature assessment of Capitalism's origins, his 'last theory of Capitalism'. This approach, developed in his book Wirtschaft und Gesellschaft, published in 1922, is far more sophisticated and institutionally complex than the better-known version delivered in "The Protestant Ethic and the Spirit of Capitalism”. Schumpeter's criticism would not fit Weber's fully developed (1922) interpretation of the rise of Capitalism. See Collins (1986) for a brilliant discussion of Weber's "last theory". As for Sombart, a proper analysis of his theory is still needed. See Reinert and Reinert (2006) for an important discussion of the idea of creative discussion in Nietzsche, Sombart and Schumpeter. 
(see ANDERSEN, 2009). In his 1939 Business Cycles, Schumpeter states, in a footnote, that he "believes, although [...] cannot stay to show, that theory [of innovation] here expounded is but a special case, adapted to the economic sphere, of a much larger theory which applies to change in all spheres of social life, science and art included" (SCHUMPETER, 1939, p. 97).

His 1912 Theorie der wirtschaftlichen Entwicklung / The Theory of Economic Development assumes apparently a similar theory, without going into details either. We can infer that what Schumpeter meant by this larger theory of change in social life is that change is driven by entrepreneurial, creative entities. Persons, or "new men" as he called them in 1939, or organizations which became his focus in 1942, that look for "new combinations", innovative solutions and bring forth evolutionary changes: entirely new ways of doing things (in business, politics, art, science, etc) that will spread, in some cases more than others, throughout the given sphere of life. ${ }^{9}$ Some of these changes will change value systems and disrupt incumbent hierarchies. ${ }^{10}$

In the seventh and last chapter of this book, ${ }^{11}$ summarizing his argument, Schumpeter argues that innovations as new combinations ("neue Kombinationen") form the internal dynamics of an economy that break the economy away from existing paths into new directions and force thus firms, individuals, and eventually institutions to adapt; for Schumpeter, such dynamics define the form of the economy ("Wirtschaftsform"). The key point is that in both passages what emerges as fundamental outcomes are disruptions and dislocations, not convergence.

Furthermore, in Schumpeter's framework the core of the 'process of economic development' is not restricted to technology. It springs from virtuous interaction among finance (credit), entrepreneurship and competition by means of innovation, which builds up as a struggle for survival and growth in a structurally uncertain environment (SCHUMPETER, 1942 [1992], part 2; O'SULLIVAN, 2006; PEREZ, 2002). Profits that result from dominant market positions are always under threat from imitative strategies or other firms' innovative behaviors; they can only be maintained by continuous product differentiation and productivity enhancement. Very importantly though, neither the process nor the outcome - successful innovations and structural change - are granted. For each Thomas Edison, Henry Ford or Steve Jobs, there are hundreds of failed attempts that end up in bankruptcy courts. Divergence again. It is important to note that such Schumpeterian divergence is

9 Schumperer (1912, p.142), German edition.

10 Schumpeter (1912, p. 157), German edition.

11 Translated into English only in 2002 in a special issue of Industry and Innovation. 
a powerful force of changing economic behavior of individuals and firms. In one sentence: Schumpeterian divergence which enforces diversity, and diversity - not convergence - is at the heart of leapfrogging processes.

In any event, firms that survive invariably innovate - that is, they exploit opportunities for change by applying new ideas, methods, or combinations of resources. Further, the innovation process is ceaseless - but success is not. The very success of firms' reactions to competitive challenges acts to reinforce uncertainty, instability, and diversity calling forth new reactions and innovations and leading to continuous economic change. Many of these innovation processes are in effect firms trying to imitate other successful companies (think how today almost every serious IT and/or electronics company tries to enter iPad market). However, success is not achieved through a one size fits all formula. It, rather, engenders massive asymmetries as it generates positive feedback from markets to producers, which translates in different competitive strategies for some and bankruptcy for many.

Firms thus compete continuously for market niches, with asymmetric results: success for some, with strengthened technological, organizational, or legal ${ }^{12}$ capabilities, and above-average (their own) past profits; failure for other firms, which either disappear or are reduced to marginal activities - or move into other business segments. Schumpeter put it as follows: "to escape being undersold, every firm is compelled to follow suit, to invest, and to accumulate" (SCHUMPETER 1942 [1992], chapter 3, p. 32). However, the key point here is that the pressure of imitation via competition does not lead to one best business practice in a given sector - that is, to convergence of business practices - but rather to continuous technological, organizational and legal change, financial innovation and differentiation; and temporary monopolization of market opportunities.

For instance, while in 1920s radio industry was one of the most dynamic industries, nobody would consider radios a dynamic sector in 2015. Yet, creative destruction processes (evolution of technological, organizational, financial, institutional capabilities) started by RCA in 1920s - leading radio manufacturer of the time - created, in succession, black-and-white and color TV industry, that in turn revolutionized news and entertainment businesses, and were instrumental in development of VCR and computer businesses, that in turn led to internet, mobile phone, and social networking. Along the way, US lost almost all capabilities to produce any consumer electronics, but of course, it gained leading positions in today's

12 Such as patents, copyrights, trademarks and a whole host of intellectual property-based monopolies. 
dynamic industries, such as internet search and social networking. In Schumpeter's framework: some industries and corporations soared ahead while others fell behind and disappeared (see also CHANDLER, 2001).

In other words, creative destruction processes bring forth not only technological changes at company level, and are not restricted to a sectorial level. These processes generate entire new industries based on technological, organizational, spatial and cultural restructuring. Electricity made radios possible, but also home appliances that transformed how food is stored that in turn made suburban living and mass consumption possible (LANDES, 1969; CHANDLER, 2001; PEREZ, 2002). In one sentence: electricity provided open-ended possibilities for developing new technologies in a whole host of sectors. Corporations used that to re-design, over and over, the 'technological frontier'... and leapfrog.

Google, Apple, Baidu or Amazon provide us with clear examples of our main proposition. Those companies have changed the way we organize our daily activities as trough successful "gales of creative destruction". Technological, organizational, spatial, legal, financial and strategic. The full Schumpeter catalog. Most importantly, however, they did not "catch-up. They leapfrogged their competitors and redesigned the "frontier". They have revolutionized entire industries and became dominant players on a global scale in a very short period of time (LEVY, 2011; ISAACSON, 2011; STONE, 2013). Obviously, these socio-economic changes are not bound by national borders. However, the nature of trade regulations and agreements makes a huge difference on how creative destruction works out in a given country, and this should be perhaps a key theme in a development agenda for the twenty first century. To conclude the section, let's state the following: leapfrogging processes not necessarily depend on, or spring from, groundbreaking scientific advances. Their kernel is the strategic use of both old and new technologies in creative ways. That requires finance and 'productivity-oriented' financial governance.

\section{Finance in Schumpeterian development processes: bringing financial Keynesianism in}

Schumpeter's theory of economic development stands on two pillars: innovations that increase productivity in production and finance that supports these innovations. Briefly summarized, for Schumpeter finance plays the role of the handmaiden of creative destruction that allows industry to produce technological advance and economic development. However, Schumpeter did not deal in detail with finance; 
in particular, he did not look at the financial system as a system that is, similarly to production system, based on innovations. Here enters Minsky. ${ }^{13}$ For Minsky, bankers are as much as industry captains are innovators, and both sides of the economy, finance and production, are intimately linked through corporation's balance sheets. The inherent uncertainty (liabilities to set up or upgrade production and/or innovate) faced by firms in a competitive environment is reflected in their financial asset's prices, in the way their cash flows and cash commitments evolve over time and, in particular, in the way financial markets evaluate them (MINSKY, 1982, 1986).

According to Minsky, modern capitalism has to be understood through what he called "The Wall Street Paradigm": "Looking at the economy from a Wall Street board room, we see a paper world - a world of commitments to pay cash today and in the future. These cash flows are a legacy of past contracts in which money today was exchanged for money in the future. In addition, we see deals being made in which commitments to pay cash in the future are exchanged for cash today. The viability of this paper world rests upon the cash flows (or gross profits after out-ofpocket costs and taxes) that business organizations, households, and governmental bodies receive as a result of the income-generating process" (MINSKY, 1982, p. 63).

According to Minsky, financial institutions are profit-seekers, and driven - in the same way that the industrial structure is - by competition and innovation. Profits arise from the exploitation and protection of their acquired/developed competitive and knowledge-based advantages. In finance, as in the production, successful innovation produces dominant competitive positions, which can only be challenged by firms that are capable of reproducing the innovation, or perfecting another technique that is more profitable and more attractive to the market. Innovations are inherent to the financial system.

However, government regulations play a prominent role in which direction financial sector innovates. It can slow down diffusion, or boost it. Financial deregulation since the seventies did precisely the latter. Every financial innovation was quickly imitated and widely diffused. The result was, however, again, not convergence but divergence. Canada, Brazil, Taiwan and China dealt with the "cluster of sub-prime prompted financial innovations" in a very different fashion than the U.S, the UK and most of Europe, and weathered the crisis much better. The key

13 It is important to note that in development theory there were important contemporaries, or in some cases similarly to Minsky students of Schumpeter, who can be viewed as forerunners here. The so-called development pioneers, perhaps most notably Ragnar Nurkse and some Latin American economists such as Raul Prebish, were well aware of the importance financial structure plays in an economy. For a discussion, see Kattel, Kregel and Reinert (2009). It would make for an intriguing discussion to contrast their views with Schumpeter and Minsky, in this paper we cannot dwele on this issue. 
point, or lesson, here is that in a financially globalized world, domestic institutions and modes of financial governance matter more than ever.

In the U.S, over the past decades what was once a bank's most important source of earnings, the net interest margin between borrowing and lending rates and the size of its deposit multiplier, has been declining dramatically. To meet this shortfall in earnings commercial banks have been forced, by competition, to innovate. To enter into other areas of activity, such as the provision of financial services in order to generate fee and commission income, by "over-leveraging" their proprietary trading in financial assets, and towards "reckless" innovations such as credit default swaps and all sorts of betting techniques with no relationship with productivity increases whatsoever (KREGEL, 1998, 2001b).

This - bad finance - is a potential outcome essentially missing from Schumpeter's framework. Here both Minsky and Kregel made their mark. Moreover, it is from their analysis that the concept of "robust financial governance" finds meaning. Robust financial governance is pivotal in determining whether the given financial system is oriented more towards funding the productive sector and sustaining innovation and development, or biased towards gambling, financial arbitrage and betting against its clients. Kregel's contribution in that realm was to show that the way financial sector is organized and governed is a core dimension of any development process.

He provided us with sharp analyses of the dysfunctional impact of unsound financial governance on development, innovation and on leapfrogging processes. Demonstrating that a Minsky crisis happened in East Asia, describing the role of derivatives in amplifying it and by analyzing the US sub-prime crisis as a Ponzi scheme from the very beginning (with no evolution from hedge and speculative phases), he linked (bad) finance to regressive development .

Furthermore, his work shows that financial systems' organization, and their impact on the productive sectors, does not only depend on domestic financial governance, but, especially in the case of developing nations, also on global processes and international institutional arrangements. Exchange rate regimes capital account management, trade openness, and international treaties play a key role in shaping development trajectories (KREGEL, 2004).

Thus, while Minsky showed that the structure of an economy consists of units with different balance sheets (hedge, speculative and Ponzi) that mirror the macro-financial evolution; Kregel has analyzed the international dimension of financial governance and how the interplay between domestic and global forces and institutions can produce hedge, speculative or Ponzi countries (or regions). 
Furthermore, Kregel has also underlined how reliance on foreign financial flows, in particular in form of short-term financial flows, tends to drag countries into Ponzi schemes (KREGEL, 2001, 2004).

Summing up, what Minsky and Kregel have shown is that Schumpeterian competition has to be supplemented by an evolutionary theory of the workings of the financial system. In other words, leapfrogging as described above is not only a technological and institutional issue, but also a financial governance matter. A policy issue of building a financial structure that leads to productive investments and helps to manage creative destruction. ${ }^{14}$

\section{Conclusion}

Schumpeterian competition - creative destruction by means of innovation - is a permanent leapfrogging process where forging ahead and falling behind are expected (predictable) results. Moreover, leapfrogging processes are not technology-driven neither techno-institutional constructs. They are outcomes of virtuous feedbacks among financial structure, financial governance and competition by means of innovations that lead to diverse technology trajectories and paradigms, and to openended institutional changes. Divergence, once again, is the norm. Furthermore, there is no fixed technological (or "financial") frontier; competition itself is a process of permanently redefining and reinventing it. Moreover, this is valid for firms, industries and countries. Development in itself is thus an open-ended and highly uncertain process where there are hardly any "best practices", since they are continually challenged by innovations and where imitation is often "creative". Financial structures and financial governance are still largely absent of that framework, but we hope to have indicated how the contributions of Keynes, Minsky and Kregel allow us to dig deeper in that bridging exercise. However, this is a task for another paper.

To conclude, we leave the reader with our opening question: convergence, catch-up or leapfrogging and finance, which is the best way to approach development history in general and, especially, the trajectories of "late developers" in the last three-four decades? By now, you know our answer. 


\section{References}

ADELMAN, J. Wordly philosopher - The odyssey of Albert O. Hirschman. Princeton: Princeton University Press, 2013.

AMSDEN, A.; HIKINO, T. Staying behind, stumbling back, sneaking up, soaring ahead: late industrialization in historical perspective. In: BAUMOL, W.; NELSON, R.; WOLFF, E. (Eds.). Convergence of productivity - cross national studies and historical evidence. Oxford: Oxford University Press, 1994.

ANDERSEN, E. A. Schumpeter's evolutionary economics. A theoretical, historical and statistical analysis of the engine of capitalism. London: Anthem, 2009.

BAUMOL, W.; NELSON, R.; WOLFF, E. (Eds.). Convergence of productivity - cross national studies and historical evidence. Oxford: Oxford University Press, 1994.

BLOCK, F.; KELLER, M. State of innovation: the U.S. government's role in technology development. Boulder, Colorado: Paradigm Publishers, 2011.

BOYER, R. The convergence hypothesis revisited: globalization but still the century of nations? In: CONFERENCE DOMESTIC INSTITUTIONS, TRADE AND THE PRESSURES FOR NATIONAL CONVERGENCE. Bellagio, Feb. 1993. Available at: <http://www. cepremap.ens.fr/depot/couv_orange/co9403.pdf>.

BURLAMAQUI, L. Finance, development and the Chinese entrepreneurial state. Brazilian Journal of Political Economy, v. 35, n. 4 (141), p. 728-744, Oct./Dec. 2015.

BURLAMAQUI, L.; KATTEL, R. Development theory: convergence, catch-up or leapfrogging? A Schumpeter-Minsky-Kregel approach. In: PAPADIMITRIOU, D. (Ed.). Contributions to economic theory, policy, development and finance: essays in honor of Jan A. Kregel. London: Palgrave Macmillan, 2014. p. 175-195.

CHANDlER, A. Scale and scope. Cambridge, Mass.: The Belknap Press of Harvard University Press, 1990.

Inventing the electronic century. Free Press, 2001.

COLLINS, R. Weberian sociological theory. Cambridge: Cambridge University Press, 1986.

CORREA, C. M. Intellectual property rights, the WTO and developing countries: the TRIPS agreement and policy options. London and New York: Zed Books, 2000.

DORE, R. Taking Japan seriously. Stanford University Press, 1987. 
FISHLOW, A. Alexander Gerschenkron: a latecomer who emerged victorious. Review of Economic Backwardness in Historical Perspective. Project 2001: Significant Works in Economic History, 2001.

FRUIN, M. The Japanese enterprise system: competitive strategies, cooperative structures. Oxford: Oxford University Press, 1992.

GALLAGHER, K.; PORZECANSKI, R. The dragon in the room: China and the future of Latin American industrialization. Stanford University Press, 2011.

GALLAGHER, K. P. (Ed.). Putting development first: the importance of policy space in the WTO and international financial institutions. London and New York: Zed Books, 2005.

GERSCHENKRON, A. Economic backwardness in historical perspective. Cambridge, MA: Harvard University Press, 1962.

GUERRIERI, P. Trade patterns, FDI, and industrial restructuring of Central and Eastern Europe. Berkeley, CA: Berkeley Roundtable on the International Economy - BRIE, 1998 (BRIE working paper series, n. 124). Available at: <http://brie.berkeley.edu/publications/ WP124.pdf>.

HIRSCHMAN, A. O. The strategy of economic development. New Haven, CT: Yale University Press, 1958.

ISAACSON, W. Steve Jobs. Simon Schuster, 2011.

JOHNSON, C. MITI and the Japanese miracle. Stanford University Press, 1982.

KARO, E.; Rainer, K. The copying paradox: why converging policies but diverging capacities for development in Eastern European innovation systems? International Journal of Institutions and Economies, v. 2, n. 2, 2010.

KATTEL, R.; KREGEL, J. A.; REINERT, E. S. The relevance of Ragnar Nurkse and classical development economics. In: KATTEL, R.; KREGEL, J. A.; REINERT, E. S. (Eds.). Ragnar Nurkse (1907-2007): classical development economics and its relevance for today. London: Anthem, 2009. p. 1-28.

KATTEL, R. Financial and economic crisis in Eastern Europe. Journal of Post Keynesian Economics, v. 33, n. 1, p. 41-60, 2010.

KEYNES, J. M. The general theory of employment, interest and money. Harcourt, 1936.

KREGEL, J. A.; BURLAMAQUI, L. Innovation, competition and financial vulnerability. Brazilian Journal of Political Economy, v. 25, n. 2, p. 5-23, 2005.

KREGEL, J. A. The past and future of banks. Ente per gli Studi Monetari, Bancari e Finanziari Luigi Einaudi. Quaderni di Ricerche, n. 21, Rome, Bank of Italy, 1998. 
Yes, "it" did happen again - the Minsky crisis in Asia. In: BELLOFIORI, R.; FERRI, P. (Eds.). Financial Keynesianism and market instability - the economic legacy of Hyman Minsky. Cheltenham: Elgar, 2001a.

. Derivatives and global capital flows: applications to Asia. In: CHANG, H. J.; PALMA, G.; WHITAKER, H. (Eds.). Financial liberalization and the Asian crisis. Palgrave, 2001b.

. External financing for development and international financial instability. October 2004. (G-24 discussion paper, n. 32).

. What would Minsky have thought of the mortgage crisis? In: PAPADIMITRIOU, D.; WRAY, R. (Eds.). The Elgar Companion to Hyman Minsky. Cheltenham: Elgar, 2010. LANDES, D. The Unbound Prometheus. Cambridge, MA: Cambridge University Press, 1969. LEVY, S. In the plex - how Google thinks, works and shapes our lives. Simon Schuster, 2011. LI, X.; CORREA, C. M. (Eds.). Intellectual property enforcement: international perspectives. Cheltenham: Elgar, 2009.

MINSKY, H. Can "IT" happen again: essays on instability and finance. Armonk, M E: Sharpe, 1982. Stabilizing an unstable economy. 1986.

NEE, V. Russia and China: the reversal of fortunes. Unpublished manuscript, 2007.

ODAGIRI, H. et al. Intellectual property rights, development, and catch up: an international comparative study. Oxford: Oxford University Press, 2011.

O'SUllivan, M. Finance and innovation. In: FAGEBERG, J. MOWERY, D. C.; NELSON, R. R. (Eds.). The Oxford handbook of innovation. Oxford: Oxford University Press, 2006. p. 240-265.

OCAMPO, J. A.; KREGEL, J. A.; GRIFFITH, J. S. (Eds.). International finance and development. Zed Books, 2007.

PEREZ, C. Technological revolutions and financial capital. Cheltenham: Elgar, 2002.

REINERT, E. How rich countries got rich... and why poor stay poor. Anthem Press, 2007.

. Emulation versus comparative advantage: competing and complementary principles in the history of economic policy. In: CIMOLI, M.; DOSI, G.; STIGLITZ, J. E. Industrial policy and development: the political economy of capabilities accumulation. Oxford: Oxford University Press, 2009a. p. 79-106. 
Production-based economic theory and the stages of economic development: from tacitus to Carlota Perez. In: DRECHSLER, W.; KATTEL, R.; REINERT, E. S. (Eds). Techno-economic paradigms - essays in honour of Carlota Perez. Anthem Press, 2009b.

REINERT, S. A. Translating empire. Emulation and the origins of political economy. Cambridge, MA: Harvard University Press, 2011.

REINERT, H.; REINERT, E. S. Creative destruction in economics: Nietzsche, Sombart, Schumpeter. In: BACKHAUS, J. G.; DRECHSLER, W. (Eds.). Friedrich Nietzsche (18441900). Economy and Society. New York: Springer, 2006. p. 55-85.

RODRIK, D. One economics, many recipes. Cambridge, MA: Cambridge University Press, 2007.

ROSTOW, W. The stages of economic growth. Cambridge, MA: Cambridge University Press, 1960.

SCHUMPETER, J. A. Theorie der wirtschaftlichen Entwicklung. Berlin: DunckerHumblot, 1912.

Business cycles. A theoretical, historical, and statistical analysis of the capitalist process. London and New York: McGraw-Hill, v. 1, 1939.

. Capitalism, socialism and democracy. Harper, 1942 [1992].

SHADLEN, K. Patents and pills, power and procedure: the north-south politics of public health in the WTO. Development Studies Institute, 2003 (Working papers, 03-42).

. Policy space for development in the WTO and beyond: the case of intellectual property rights. Global Development and Environment Institute, 2005 (Working papers, 05-06).

STONE, B. The everything store. Jeff Bezos and the Age of Amazon, 2013.

STUDWELL, J. How Asia works. Grove Press, 2013.

THRASHER, R. D.; GALLAGHER, K. $21^{\text {st }}$ century trade agreements: implications for long-run development policy. Boston MA: Boston University, 2008 (The Pardee papers, 2).

VOGEL, E. Japan as number one. Cambridge, MA: Harvard University Press, 1979.

WADE, R. What strategies are viable for developing countries today? The world trade organization and the shrinking of 'development space. Review of International Political Economy, v. 10, n. 4, p. 621-644, 2003.

WATSON, P. The German genius: Europe's third renaissance, the second scientific revolution, and the twentieth century. Harper, 2011.

WEISS, L. America Inc? Innovation and enterprise in the national security state. New York: Cornell University Press, 2014. 